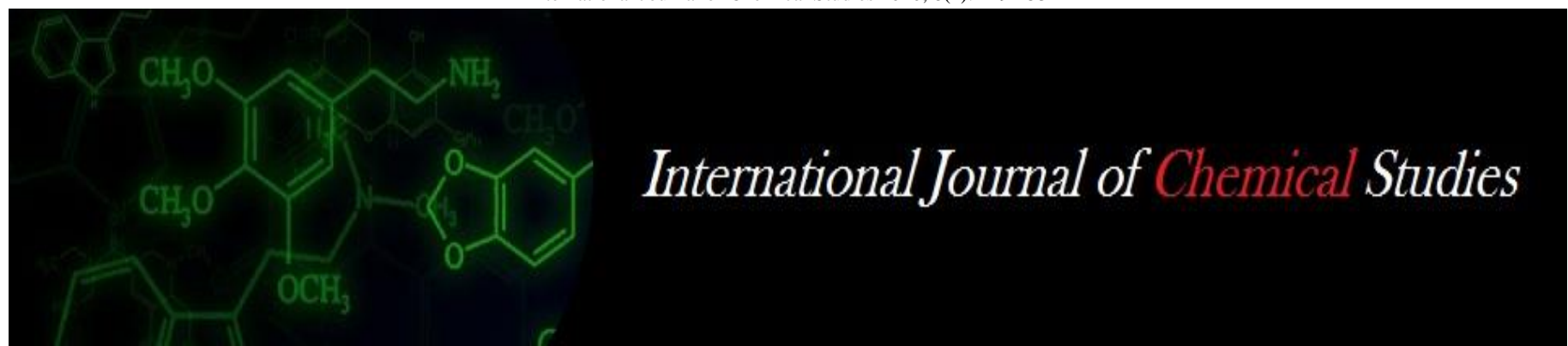

P-ISSN: 2349-8528

E-ISSN: 2321-4902

www.chemijournal.com

IJCS 2020; 8(2): 249-253

(C) 2020 IJCS

Received: 19-01-2020

Accepted: 21-02-2020

Durgeshwar Kumar Basant Department of Floriculture and Landscape Architecture, IGKV, Raipur, Chhattisgarh, India

\section{LS Verma}

Department of Floriculture and Landscape Architecture, IGKV, Raipur, Chhattisgarh, India

\section{Ram Singh}

Department of Floriculture and Landscape Architecture, IGKV, Raipur, Chhattisgarh, India

Ishwar Ram Markam Department of Floriculture and Landscape Architecture, IGKV, Raipur, Chhattisgarh, India

Corresponding Author: Durgeshwar Kumar Basant Department of Floriculture and Landscape Architecture, IGKV, Raipur, Chhattisgarh, India

\section{Effect of nutrient management on growth, flowering and flower yield of tuberose (Polianthes tuberose $\mathrm{L}$.) under Chhattisgarh plain condition}

\author{
Durgeshwar Kumar Basant, LS Verma, Ram Singh and Ishwar Ram \\ Markam
}

\section{DOI: https://doi.org/10.22271/chemi.2020.v8.i2d.8778}

\begin{abstract}
The present investigation was conducted in the year 2016-17 at the Department of Floriculture and Landscape Architecture, IGKV, Raipur, Chhattisgarh for the effect of integrated nutrient management on growth, flowering and flower yield of tuberose. Ten treatment combinations of different fertilizer and organic manure nutrients were comprised with three replications. Result showed the significant result and the maximum plant height, leaf length, fresh weight, dry weight, number of florets spike ${ }^{-1}$, length of spike $^{-1}$, length of rachis and flower yield were recorded under T9 $\left(75 \%\right.$ RDF + FYM @ $3.5 \mathrm{t} \mathrm{ha}^{-1}+$ Vermicompost@1.5 tha $\mathrm{th}^{-1}$ +Poultry manure @ $\left.2 \mathrm{t} \mathrm{ha}^{-1}\right)$ followed by T7 $\left(50 \% \mathrm{RDF}+\mathrm{FYM} @ 10 \mathrm{t} \mathrm{ha}^{-1}+\right.$ Poultry manure@ $2 \mathrm{t} \mathrm{ha}^{-1}$ ). The maximum number of leaves plant ${ }^{-1}$, and diameter of floret were found under $\mathrm{T}_{7}\left(50 \% \mathrm{RDF}+\mathrm{FYM} @ 10 \mathrm{t} \mathrm{ha}^{-1}+\right.$ Poultry manure @2 $\left.\mathrm{t} \mathrm{ha}^{-1}\right)$ whereas the weight of 100 florets was recorded maximum under $\mathrm{T}_{8}\left(50 \% \mathrm{RDF}+\right.$ Vermicompost @ $5 \mathrm{t} \mathrm{ha}^{-1}+$ Poultry manure @ $\left.2 \mathrm{tha}^{-1}\right)$.
\end{abstract}

Keywords: Tuberose, growth, flowering, vase life and yield

\section{Introduction}

Tuberose (Polianthes tuberosa L.) belongs to family Agavaceae and is native of Mexico. It is a one of the most important tropical bulbous flowering plants cultivated for production of long lasting flower spikes. It is popularly known as Rajanigandha. Commercial importance of tuberose is due to beauty of the flower, longer vase-life of spikes and aromatic oil extracted from its fragrant white flower. The tuberose blooms throughout the year, florets are star shaped, waxy and loosely arranged on spike that can reach up to 30 to $45 \mathrm{~cm}$ in length. There is high demand for tuberose concrete and absolute in international markets which fetch very good price. Flowers of the Single type (single row of perianth) are commonly used as loose flowers, making garland and essential oil etc, while the double varieties (more than two rows of perianth) are used as cut flowers, garden display and interior decoration. Tuberose which occupies place in ornamental horticulture is one of the commercially exploited flower crops. It produces attractive, elegant and fragrant white flowers. It occupies a very selective and special position to flower loving people because of its prettiness, elegance and sweet pleasant fragrance. It has a great economic potential for cut flower trade and essential oil industry (Alan et al., 2007) [1]. The flowers remain fresh for quite a long time and stand distance transportation and fill a useful place in the flower market (Patil et al., 1999) ${ }^{[13]}$. The long spikes of tuberose are used for vase decoration and bouquet preparation whereas the florets were used for artistic garlands preparation, ornaments and buttonhole use. The flowers emit a delightful fragrance are the source of tuberose oil. The natural flower oil of tuberose is one of the most expensive perfume raw materials. Tuberose is grown commercially in tropical and sub-tropical areas of world. In India, commercial cultivation of tuberose is popular in West Bengal, Tamil Nadu, Maharashtra, Andhra Pradesh, Karnataka, Assam, Rajasthan, Gujarat, Uttar Pradesh, Punjab and Chhattisgarh.

The growing period of tuberose is normally one year or more. Therefore, a high amount of organic and inorganic fertilizers are needed to maintain sustainable growth and flowering over a long period. Tuberose is a gross feeder and requires a large quantity of NPK both in the form of organic and inorganic fertilizers (Amarjeet et al., 2000) ${ }^{[2]}$. 
The effect of chemical fertilizers and organic manures on tuberose production has been reported by several authors for different geographical regions (Yadav et al., 1985 and Shankar et al., 2010) [23, 17]. Nitrogen, phosphorus and potassium have a significant effect on spike production and floret quality (Singh et al., 2005) [21]. Poultry manure is excellent organic manure as it contains high nitrogen, phosphorus, potassium and other essential nutrients (Garg et al., 2008) ${ }^{[8]}$.Vermicompost has been shown to have high levels of total and available nitrogen, phosphorus, potassium, micronutrients, and growth regulators as well as microbial and enzymatic activities (Chaoui et al., 2003) ${ }^{[3]}$.

The tuberose is a voracious feeder of NPK and responds well to the organic and inorganic nutrient application particularly nitrogenous fertilizers as it is major nutrients required for the optimum growth, development and flowering of tuberose, it has greater influence right from cell division to the development of vegetative and reproductive organs (Sadhu and Bose, 1973) ${ }^{[16]}$.

\section{Materials and Methods}

The present experiment was conducted at the Horticultural Research cum Instruction Farm of the Department of Floriculture and Landscape Architecture, College of Agriculture, Indira Gandhi Krishi Vishwavidyalaya, Raipur, Chhattisgarh, during 2016-17. The experiment was laid out in Randomized Block Deign (RBD) with ten treatments and three replication. The different treatments were $\mathrm{T}_{1}: 100 \%$ $\mathrm{RDF}, \mathrm{T}_{2}: 50 \% \mathrm{RDF}+\mathrm{FYM}\left(20 \mathrm{t} \mathrm{ha}^{-1}\right), \mathrm{T}_{3}: 50 \% \mathrm{RDF}+$ Vermicompost $\left(10 \mathrm{t} \mathrm{ha}^{-1}\right), \mathrm{T}_{4}: 50 \% \mathrm{RDF}+$ Poultry manure $(4 \mathrm{t}$ ha $\left.^{-1}\right), \mathrm{T}_{5}$ : (50\% RDF + FYM @ $7 \mathrm{t} \mathrm{ha}^{-1}+$ Vermicompost @ 3 $\mathrm{t} \mathrm{ha}^{-1}+$ Poultry manure @ $\left.1.5 \mathrm{t} \mathrm{ha}^{-1}\right), \mathrm{T}_{6}:(50 \% \mathrm{RDF}+\mathrm{FYM}$ @ $10 \mathrm{t} \mathrm{ha}^{-1}+$ Vermicompost @ $\left.5 \mathrm{t} \mathrm{ha}^{-1}\right), \mathrm{T}_{7}:(50 \% \mathrm{RDF}+$ FYM@10 tha ${ }^{-1}+$ Poultry manure @ $\left.2 \mathrm{t} \mathrm{ha}^{-1}\right), \mathrm{T}_{8}$ : (50\% RDF +Vermicompost@5 $\mathrm{t} \mathrm{ha}^{-1}+$ Poultry manure @ $\left.2 \mathrm{t} \mathrm{ha}^{-1}\right), \mathrm{T}_{9}$ : (75\% RDF+FYM@3.5 $\left.\mathrm{tha}^{-1}\right)+$ Vermicompost @ $1.5 \mathrm{tha}^{-1}$ + Poultry manure @ $2 \mathrm{t} \mathrm{ha}^{-1}$ ) and $\mathrm{T}_{10}$ : (Control).Standard cultivation and recommended cultural practices were followed. The bulbs were planting at a distance of $30 \times 30 \mathrm{~cm}$. The observations for vegetative parameters including plant height $(\mathrm{cm})$, number of leaves plant ${ }^{-1}$, leaf length $(\mathrm{cm})$, fresh weight of leaves $(\mathrm{g})$, dry weight of leaves $(\mathrm{g})$ were recorded at15, 30, 60 and 75 days after planting (DAP). The floral characters observed were length of spike, rachis length $(\mathrm{cm})$, number of florets Spike ${ }^{-1}$, diameter of florets $(\mathrm{cm})$, weight of 100 florets $(\mathrm{g})$, flowers Yield $\mathrm{m}^{-1}$.

\section{Results and Discussion \\ Vegetative parameters}

The observation on plant height, number of leaves per plant, length of leaves, fresh weight of leaves and dry weight of leaves were recorded periodically at 15, 30, 45, 60 and 75 days after planting (DAP) as influenced by different treatments and the data are given in (Table 1and Table 2)

The maximum plant height $(24.25 \mathrm{~cm})$ at 15 DAP was recorded in treatment $\mathrm{T}_{9}\left(75 \% \mathrm{RDF}+\mathrm{FYM}\left(3.5 \mathrm{t} \mathrm{ha}^{-1}\right)+\right.$ Vermicompost $\left(1.5 \mathrm{t} \mathrm{ha}^{-1}\right)+$ Poultry manure $\left(2 \mathrm{t} \mathrm{ha}^{-1}\right)$ which was significantly superior over all the treatments except $\mathrm{T}_{1}$ (100\% RDF), $\mathrm{T}_{7}\left(50 \% \mathrm{RDF}+\mathrm{FYM} 10 \mathrm{t} \mathrm{ha}^{-1}\right)+$ Poultry manure $\left(2 \mathrm{t} \mathrm{ha}^{-1}\right)$ which is at par. Minimum plant height $(13.82 \mathrm{~cm})$ was observed in treatment $\mathrm{T}_{10}$ Control.

The maximum plant height $(28.75 \mathrm{~cm})$ at 30 DAP was recorded in treatment $\mathrm{T}_{9}\left(75 \% \mathrm{RDF}+\mathrm{FYM}\left(3.5 \mathrm{t} \mathrm{ha}^{-1}\right)+\right.$ Vermicompost $\left(1.5 \mathrm{t} \mathrm{ha}^{-1}\right)+$ Poultry manure $\left(2 \mathrm{t} \mathrm{ha}^{-1}\right)$ which was significantly superior over treatments $T_{1}$ to $T_{6}$. However, it was statistically at par with $\mathrm{T}_{7}\left(50 \% \mathrm{RDF}+\mathrm{FYM} 10 \mathrm{t} \mathrm{ha}^{-1)}\right.$ + Poultry manure $\left(2 \mathrm{t} \mathrm{ha}^{-1}\right)$ and $\mathrm{T}_{8} \quad(50 \% \mathrm{RDF}+$ Vermicompost $\left(5 \mathrm{t} \mathrm{ha}^{-1}\right)+$ Poultry manure $\left(2 \mathrm{t} \mathrm{ha}^{-1}\right)$. The minimum plant height $(20.34 \mathrm{~cm})$ was observed in treatment $\mathrm{T}_{10}$ Control.

The observed data at 45 and 60 DAP clearly indicated that the maximum plant height $(31.78 \mathrm{~cm}$, and $34.09 \mathrm{~cm}$ respectively) was observed in treatment $\mathrm{T}_{9}$ and it was significantly superior over all the treatments. The minimum plant height $(22.01 \mathrm{~cm}$ and $24.44 \mathrm{~cm}$ respectively) was observed in treatment $\mathrm{T}_{10}$ Control.

The maximum plant height $(36.24 \mathrm{~cm})$ at 75 DAP was recorded in treatment $\mathrm{T}_{9}\left(75 \% \mathrm{RDF}+\mathrm{FYM} 3.5 \mathrm{t} \mathrm{ha}^{-1}\right)+$ Vermicompost $\left(1.5 \mathrm{t} \mathrm{ha}^{-1}\right)+$ Poultry manure $\left(2 \mathrm{tha}^{-1}\right)$ which was significantly superior over treatments $T_{1}, T_{2}, T_{4}, T_{5}$, and $\mathrm{T}_{6}$. However, it was statistically at par with $\mathrm{T}_{3}(50 \% \mathrm{RDF}+$ Vermicompost $\left(10 \mathrm{t} \mathrm{ha}^{-1}\right), \mathrm{T}_{7}\left(50 \% \mathrm{RDF}+\mathrm{FYM} 10 \mathrm{t} \mathrm{ha}^{-1}\right)+$ Poultry manure $\left(2 \mathrm{t} \mathrm{ha}^{-1}\right)$ and $\mathrm{T}_{8}(50 \% \mathrm{RDF}+$ Vermicompost $\left(5 \mathrm{t} \mathrm{ha}^{-1}\right)+$ Poultry manure $\left(2 \mathrm{t} \mathrm{ha}^{-1}\right)$. The minimum plant height $(28.69 \mathrm{~cm})$ was observed in treatment $\mathrm{T}_{10}$ Control.

The result shows nitrogen and phosphorus had positive correlation with the plant height, it nutrient availability is increased with increase in organic sources viz. FYM, vermicompost and Poultry manure $\left(\mathrm{T}_{9}, \mathrm{~T}_{8}, \mathrm{~T}_{7}\right)$. Nitrogen, a constituent of protein and is essential for formation of protoplasm, cell division and cell enlargement, while phosphorus a part of nucleic acids and also responsible for root development and the combined effect of higher availability of both nutrients in plant vicinity enhance the vegetative growth of the plant.(Dahiya et al. 2001 and Yadav et al., 2005) ${ }^{[6,24]}$.

With respect to number of leaves per plant at different growth stages are presented in the Table 1. At 15 DAP the maximum number of leaves (10.09) at 15 DAP was observed in treatment $\mathrm{T}_{7}\left(50 \%\right.$ RDF + FYM $\left(10 \mathrm{t} \mathrm{ha}^{-1}\right)+$ Poultry manure (2 $\mathrm{t} \mathrm{ha}^{-1}$ ) which was significantly superior over all the treatments except $\mathrm{T}_{3}, \mathrm{~T}_{5}, \mathrm{~T}_{6}$, and $\mathrm{T}_{9}$. The minimum number of leaves per plant (4.83) was observed in treatment $\mathrm{T}_{10}$ Control. The maximum number of leaves (17.69) at 30 DAP was observed in treatment $\mathrm{T}_{7}\left(50 \% \mathrm{RDF}+\mathrm{FYM}\left(10 \mathrm{t} \mathrm{ha}^{-1}\right)+\right.$ Poultry manure $\left(2 \mathrm{t} \mathrm{ha}^{-1}\right)$ which was significantly superior over all the treatments except $\mathrm{T}_{6}\left(50 \% \mathrm{RDF}+\mathrm{FYM}\left(10 \mathrm{t} \mathrm{ha}^{-1}\right)\right.$ + Vermicompost $\left(5 \mathrm{t} \mathrm{ha}^{-1}\right)$ while at par with $\mathrm{T}_{6}$ treatment. The minimum number of leaves per plant (8.93) was observed in treatment $\mathrm{T}_{10}$ Control.

At 45, 60 and 75 DAP the maximum number of leaves (21.33, 24.33 and 29.73 respectively) was observed in treatment $\mathrm{T}_{7}$ $\left(50 \% \mathrm{RDF}+\mathrm{FYM}\left(10 \mathrm{t} \mathrm{ha}^{-1}\right)+\right.$ Poultry manure $\left(2 \mathrm{t} \mathrm{ha}^{-1}\right)$ which was significantly superior over all the treatments except $\mathrm{T}_{5}, \mathrm{~T}_{6}$ where as significant difference was found with rest of the treatment. The minimum number of leaves per plant $(11.87,14.27$ and 19.67 respectively) was observed in treatment $\mathrm{T}_{10}$ Control. Kabir et al (2011) ${ }^{[9]}$ also noted that the number of leaves was significantly increased with the application of half of chemical fertilizer along with $20 \mathrm{t} \mathrm{ha}^{-1}$ poultry manure in tuberose.

The maximum length of leaves $(9.96 \mathrm{~cm})$ at 15 DAP was observed in treatment $\mathrm{T}_{9}\left(75 \% \mathrm{RDF}+\mathrm{FYM}\left(3.5 \mathrm{t} \mathrm{ha}^{-1}\right)+\right.$ Vermicompost $\left(1.5 \mathrm{tha}^{-1}\right)+$ Poultry manure $\left(2 \mathrm{tha}^{-1}\right)$ which was significantly superior over treatments $T_{1}, T_{2}, T_{3}, T_{4}, T_{5}$, $\mathrm{T}_{6}, \mathrm{~T}_{8}$, and $\mathrm{T}_{10}$ but it was statistically at par with $\mathrm{T}_{7}$. The minimum length of leaves (4.77) was observed in treatment $\mathrm{T}_{10}$ (Control).

At 30 and 45 DAP, the data indicates that the maximum leaf length was recorded in treatment $T_{9}(16.25$ and $26.18 \mathrm{~cm})$ 
which was at par with $\mathrm{T}_{3}, \mathrm{~T}_{7}$, and $\mathrm{T}_{8}$ treatments. Minimum length of leaves $(9.75$ and $15.01 \mathrm{~cm})$ was observed in treatment $\mathrm{T}_{10}$ Control.

At 60 DAP, the maximum leaf length was recorded in treatment $\mathrm{T}_{9}(33.86 \mathrm{~cm})$, but it was at par with treatment $\mathrm{T}_{7}$ $(31.80 \mathrm{~cm})$. The minimum leaf length was recorded in treatment $\mathrm{T}_{10}(21.37 \mathrm{~cm})$.

At 75 DAP, the maximum leaf length was recorded in treatment $\mathrm{T}_{9}(40.05 \mathrm{~cm})$ but it was at par with treatment $\mathrm{T}_{7}$ $(37.15 \mathrm{~cm})$. The minimum leaf length was recorded in treatment $\mathrm{T}_{10}(28.25 \mathrm{~cm})$. The results revealed that length of leaves were greater with organic fertilizer application along with chemical fertilizers. These results indicate that application of organic fertilizers had tremendous effects on plant growth and development in tuberose. Further the effect was more pronounce in FYM + vermicompost + poultry manure combination followed by FYM + poultry manure combination. These results have conformity with the result of Padaganur et al. (2010) ${ }^{[11]}$ who reported that application of organic fertilizers along with chemical fertilizers enhanced plant growth and development in tuberose.

The maximum fresh weight of leaves was reported in treatment $\mathrm{T}_{9}(5.30 \mathrm{~g})$ at $15 \mathrm{DAP}$ which was superior over all the treatments but at par with $\mathrm{T}_{7}(4.82 \mathrm{~g})$. The minimum fresh weight of the leaves was recorded in treatment $\mathrm{T}_{10}(2.00 \mathrm{~g})$. The maximum fresh weight of leaves was reported in treatment $\mathrm{T}_{9}(6.05 \mathrm{~g})$ at $30 \mathrm{DAP}$ which was superior over all the treatments but at par with $\mathrm{T}_{7}(5.31 \mathrm{~g}), \mathrm{T}_{8}(5.23 \mathrm{~g})$. The minimum fresh weight of the leaves was recorded in treatment $\mathrm{T}_{10}(3.00 \mathrm{~g})$. The maximum fresh weight of leaves was reported in treatment $\mathrm{T}_{9}(7.03 \mathrm{~g})$ at $45 \mathrm{DAP}$ which was superior over all the treatments but at par with $\mathrm{T}_{7}(6.18 \mathrm{~g})$. The minimum fresh weight of the leaves was recorded in treatment $\mathrm{T}_{10}(3.55 \mathrm{~g})$. The maximum fresh weight of leaves was recorded in treatment $\mathrm{T}_{9}(8.03 \mathrm{~g})$ at $60 \mathrm{DAP}$ which was superior over all the treatments but at par with $\mathrm{T}_{3}(7.00 \mathrm{~g})$ and $\mathrm{T}_{7}(7.29 \mathrm{~g})$. The minimum fresh weight of the leaves was recorded in treatment $\mathrm{T}_{10}(3.70 \mathrm{~g})$. The maximum fresh weight of leaves was observed in treatment T9 $(8.75 \mathrm{~g})$ at 75 DAP which was superior over all the treatments but at par with $\mathrm{T}_{3}(7.01 \mathrm{~g}), \mathrm{T}_{7}(7.50 \mathrm{~g})$. The minimum fresh weight of the leaves was recorded in treatment $\mathrm{T}_{10}(3.89 \mathrm{~g})$.

The maximum dry weight of leaves $(0.70 \mathrm{~g})$ at 15 DAP was recorded in treatment $\mathrm{T}_{9}\left(75 \% \mathrm{RDF}+\mathrm{FYM}\left(3.5 \mathrm{t} \mathrm{ha}^{-1}\right)+\right.$ Vermicompost $\left(1.5 \mathrm{t} \mathrm{ha}^{-1}\right)+$ Poultry manure $\left(2 \mathrm{t} \mathrm{ha}^{-1}\right)$. The minimum dry weight of leaves $(0.21 \mathrm{~g})$ was recorded in treatment $\mathrm{T}_{10}$ Control. The maximum dry weight of leaves $(1.11 \mathrm{~g})$ at $30 \mathrm{DAP}$ was recorded in treatment $\mathrm{T}_{9}(75 \% \mathrm{RDF}+$ FYM $\left(3.5 \mathrm{t} \mathrm{ha}^{-1}\right)+$ Vermicompost $\left(1.5 \mathrm{t} \mathrm{ha}^{-1}\right)+$ Poultry manure $\left(2 \mathrm{tha}^{-1}\right)$ and the minimum dry weight of leaves $(0.68$ g) was recorded in treatment $\mathrm{T}_{10}$ Control. The maximum dry weight of leaves in gram $(1.16 \mathrm{~g})$ at $45 \mathrm{DAP}$ was recorded in treatment $\mathrm{T}_{9}\left(75 \%\right.$ RDF + FYM $\left(3.5 \mathrm{t} \mathrm{ha}^{-1}\right)+$ Vermicompost $\left(1.5 \mathrm{t} \mathrm{ha}^{-1}\right)+$ Poultry manure $\left(2 \mathrm{tha}^{-1}\right)$ and the minimum dry weight of leaves $(0.69 \mathrm{~g})$ was recorded in treatment $\mathrm{T}_{10}$ Control. The maximum dry weight of leaves in gram $(1.20 \mathrm{~g})$ at 60 DAP was recorded in treatment $\mathrm{T}_{9}(75 \% \mathrm{RDF}+\mathrm{FYM}$ $\left(3.5 \mathrm{tha}^{-1}\right)+$ Vermicompost $\left(1.5 \mathrm{t} \mathrm{ha}^{-1}\right)+$ Poultry manure $(2 \mathrm{t}$ $\left.\mathrm{ha}^{-1}\right)$ and the minimum dry weight of leaves $(0.70 \mathrm{~g})$ was recorded in treatment $T_{10}$ Control. The maximum dry weight of leaves in gram $(1.24 \mathrm{~g})$ at 75 DAP was recorded in treatment $\mathrm{T}_{9}\left(75 \%\right.$ RDF + FYM $\left(3.5 \mathrm{t} \mathrm{ha}^{-1}\right)+$ Vermicompost $\left(1.5 \mathrm{t} \mathrm{ha}^{-1}\right)+$ Poultry manure $\left(2 \mathrm{tha}^{-1}\right)$ and the minimum dry weight of leaves $(0.73 \mathrm{~g})$ was recorded in treatment $\mathrm{T}_{10}$ Control.

Table 1: Effect of nutrient management on Plant height, number of leaves plant ${ }^{-1}$ and length of leaves of leaves in tuberose

\begin{tabular}{|c|c|c|c|c|c|c|c|c|c|c|c|c|c|c|c|}
\hline \multirow{3}{*}{ Treatments } & \multicolumn{5}{|c|}{ Plant height (cm) } & \multicolumn{5}{|c|}{ Number of leaves plant ${ }^{-1}$} & \multicolumn{5}{|c|}{ Length of leaves $(\mathrm{cm})$} \\
\hline & 15 & 30 & 45 & 60 & 75 & 15 & 30 & 45 & 60 & 75 & 15 & 30 & 45 & 60 & 75 \\
\hline & DAP & DAP & DAP & DAP & DAP & DAP & DAP & DAP & DAP & DAP & DAP & DAP & DAP & DAP & DAP \\
\hline $\mathrm{T}_{1}: 100 \% \mathrm{RDP}(180: 60: 40) \mathrm{NPK}$ & 22.11 & 23.86 & 24.04 & 25.07 & 29.87 & 6.45 & 11.93 & 15.33 & 17.20 & 21.73 & 6.41 & 12.78 & 17.15 & 22.33 & 30.66 \\
\hline $\mathrm{T}_{2}: 50 \% \mathrm{RDF}+\mathrm{FYM}(20 \mathrm{t}$ ha- 1$)$ & 19.10 & 23.34 & 26.28 & 27.26 & 33.03 & 8.24 & 14.00 & 16.38 & 19.60 & 24.53 & 7.36 & 14.43 & 20.19 & 25.33 & 32.33 \\
\hline $\mathrm{T}_{3}: 50 \%$ RDF + Vermicompost $\left(10 \mathrm{t} \mathrm{ha}^{-1}\right)$ & 19.12 & 24.67 & 27.07 & 29.22 & 33.51 & 8.47 & 14.35 & 17.20 & 20.87 & 25.17 & 7.59 & 15.15 & 20.31 & 27.07 & 34.07 \\
\hline $\mathrm{T}_{4}: 50 \%$ RDF + Poultry manure $\left(4 \mathrm{t} \mathrm{ha}^{-1}\right)$ & 17.60 & 22.03 & 24.44 & 26.09 & 30.77 & 7.39 & 12.67 & 14.77 & 17.93 & 22.60 & 6.73 & 13.00 & 17.62 & 22 & 30.16 \\
\hline $\begin{array}{c}\mathrm{T}_{5}: 50 \% \text { RDF + FYM }\left(7 \mathrm{t} \mathrm{ha}^{-1}\right)+\text { Vermicompost } \\
\left(3 \mathrm{tha}^{-1}\right)+\text { Poultry manure }\left(1.5 \mathrm{tha}^{-1}\right) \\
\end{array}$ & 18.5 & 23.09 & $25.65 \mid$ & 27.10 & 32.23 & 9.29 & 15.55 & 19.33 & 21.80 & 27.00 & 6.68 & 13.17 & 19.08 & 24.9 & 32.29 \\
\hline $\begin{array}{c}\mathrm{T}_{6}: 50 \% \text { RDF + FYM }\left(10 \mathrm{t} \mathrm{ha}^{-1}\right)+\text { Vermicompost } \\
\left(5 \mathrm{t} \mathrm{ha}^{-1}\right)\end{array}$ & 1 & 22.57 & 25 & 26 & 31.23 & 9.93 & 16. & 19 & 22.20 & 27.40 & 6.77 & 13. & $18 .($ & 230 & 0.02 \\
\hline $\begin{array}{c}\text { T7:50\% RDF + FYM }\left(10 \mathrm{t} \mathrm{ha}^{-1}\right)+\text { Poultry manure } \\
\left(2 \mathrm{t} \mathrm{ha}^{-1}\right)\end{array}$ & & 26.20 & 30.02 & 32.23 & 34.68 & 10.09 & 17.69 & 21.33 & 24.33 & 29.73 & 8.65 & 16.1 & 22.0 & 31.80 & $\mid 37.15$ \\
\hline $\begin{array}{rl}\mathrm{T}_{8}: 50 \% & \mathrm{RDF}+\text { Vermicompost }\left(5 \mathrm{t} \mathrm{ha}^{-1}\right)+ \\
\text { Poultry manure }\left(2 \mathrm{t} \mathrm{ha}^{-1}\right)\end{array}$ & 19.15 & 26 & 29.57 & 30.04 & 33.71 & 7.67 & 13.13 & 16.00 & 18.58 & 24.00 & 7.64 & 15.7 & 21.0 & 28.31 & $35.21 \mid$ \\
\hline $\begin{array}{c}\text { T9:75\% RDF + FYM }\left(3.5 \mathrm{t} \mathrm{ha}^{-1}\right)+\text { Vermicompost } \\
\left(1.5 \mathrm{t} \mathrm{ha}^{-1}\right)+\text { Poultry manure }\left(2 \mathrm{t} \mathrm{ha}^{-1}\right)\end{array}$ & & 28.75 & 3 & 3 & 36.24 & 8.87 & 15.17 & 18.2 & 21.00 & 26.13 & 9.96 & 17.2 & 2618 & 33.8 & 10. \\
\hline $\mathrm{T}_{10}$ :Control & 13.82 & 19.34 & 22.01 & 24.44 & 28.69 & 4.83 & 8.93 & 11.87 & 14.27 & 19.67 & 4.77 & 9.75 & 15.01 & 21.37 & 28.25 \\
\hline S. Em \pm & 0.87 & 0.92 & 0.97 & 1.09 & 1.05 & 0.57 & 0.59 & 0.70 & 0.93 & 1.08 & 0.44 & 0.71 & 1.02 & 0.88 & 0.97 \\
\hline C.D at $5 \%$ & 2.60 & 2.74 & 2.89 & 3.26 & 3.12 & 1.70 & 1.76 & 2.08 & 2.78 & 3.22 & 1.33 & 2.11 & 3.04 & 2.44 & 2.98 \\
\hline
\end{tabular}

Table 2: Effect of nutrient management on fresh weight of leaves and dry weight of leaves in tuberose

\begin{tabular}{|c|c|c|c|c|c|c|c|c|c|c|}
\hline \multirow{3}{*}{ Treatments } & \multicolumn{5}{|c|}{ Fresh weight of leaves $(\mathrm{g})$} & \multicolumn{5}{|c|}{ Dry weight of leaves $(g)$} \\
\hline & 15 & 30 & 45 & 60 & 75 & 15 & 30 & 45 & 60 & 75 \\
\hline & DAP & DAP & DAP & DAP & DAP & DAP & DAP & DAP & DAP & DAP \\
\hline $\mathrm{T}_{1}: 100 \%$ RDF (180:60:40) NPK & 3.27 & 3.59 & 3.95 & 4.69 & 6.06 & 0.34 & 0.81 & 0.83 & 0.85 & 0.87 \\
\hline $\mathrm{T}_{2}: 50 \%$ RDF + FYM $\left(20 \mathrm{t} \mathrm{ha}^{-1}\right)$ & 4.00 & 4.25 & 4.72 & 5.72 & 6.72 & 0.34 & 0.85 & 0.86 & 0.88 & 0.90 \\
\hline $\mathrm{T}_{3}: 50 \%$ RDF + Vermicompost $\left(10 \mathrm{t} \mathrm{ha}^{-1}\right)$ & 4.28 & 5.03 & 5.45 & 7.00 & 7.01 & 0.35 & 0.72 & 0.75 & 0.76 & 0.78 \\
\hline $\mathrm{T}_{4}: 50 \%$ RDF + Poultry manure $\left(4 \mathrm{t} \mathrm{ha}^{-1}\right)$ & 3.33 & 3.69 & 4.05 & 5.12 & 6.21 & 0.40 & 0.74 & 0.76 & 0.79 & 0.81 \\
\hline $\mathrm{T}_{5}: 50 \%$ RDF + FYM $\left(7 \mathrm{t} \mathrm{ha}^{-1}\right)+$ Vermicompost $\left(3 \mathrm{t} \mathrm{ha}^{-1}\right)+$ Poultry manure $\left(1.5 \mathrm{t} \mathrm{ha}^{-1}\right)$ & 3.84 & 3.92 & 4.45 & 5.03 & 6.61 & 0.32 & 0.77 & 0.79 & 0.81 & 0.83 \\
\hline $\mathrm{T}_{6}: 50 \%$ RDF + FYM $\left(10 \mathrm{t} \mathrm{ha}^{-1}\right)+$ Vermicompost $\left(5 \mathrm{t} \mathrm{ha}^{-1}\right)$ & 3.35 & 3.74 & 4.20 & 4.71 & 6.36 & 0.30 & 0.78 & 0.80 & 0.82 & 0.84 \\
\hline
\end{tabular}




\begin{tabular}{|c|c|c|c|c|c|c|c|c|c|c|}
\hline T7:50\% RDF + FYM $\left(10 \mathrm{t} \mathrm{ha}^{-1}\right)+$ Poultry manure $\left(2 \mathrm{t} \mathrm{ha}^{-1}\right)$ & 4.82 & 5.31 & 6.18 & 7.29 & 7.50 & 0.39 & 0.73 & 0.75 & 0.77 & 0.79 \\
\hline $\mathrm{T}_{8}: 50 \%$ RDF + Vermicompost $\left(5 \mathrm{t} \mathrm{ha}^{-1}\right)+$ Poultry manure $\left(2 \mathrm{t} \mathrm{ha}^{-1}\right)$ & 4.41 & 5.23 & 5.72 & 6.04 & 7.17 & 0.37 & 0.72 & 0.74 & 0.78 & 0.91 \\
\hline $\mathrm{T}_{9}:$ 75\% RDF + FYM $\left(3.5 \mathrm{t} \mathrm{ha}^{-1}\right)+$ Vermicompost $\left(1.5 \mathrm{t} \mathrm{ha}^{-1}\right)+$ Poultry manure \\
$\left(2 \mathrm{t} \mathrm{ha}^{-1}\right)$ & 5.30 & 6.05 & 7.03 & 8.03 & 8.75 & 0.70 & 1.11 & 1.16 & 1.20 & 1.24 \\
\hline T $_{10}:$ Control $_{\text {S.Em } \pm}$ & 2.00 & 3.00 & 3.55 & 3.70 & 3.89 & 0.21 & 0.68 & 0.69 & 0.70 & 0.73 \\
\hline C.D at 5\% & 0.23 & 0.28 & 0.30 & 0.42 & 0.38 & 0.02 & 0.04 & 0.04 & 0.06 & 0.09 \\
\hline & 0.69 & 0.90 & 0.91 & 1.25 & 1.13 & 0.08 & 0.14 & 0.13 & 0.20 & 0.23 \\
\hline
\end{tabular}

\section{Flower characters and yield}

The observation on length of spike, length of rachis, number of florets spike ${ }^{-1}$, diameter of florets, weight of 100 florets and flowers yield $\left(\mathrm{kg} \mathrm{m}^{-2}\right)$ were recorded as influenced by different treatments and the data are given in (Table 3 )

The maximum length of spike $(72.33 \mathrm{~cm})$ was recorded in the treatment $\mathrm{T}_{9}\left(75 \%\right.$ RDF + FYM $\left(3.5 \mathrm{t} \mathrm{ha}^{-1}\right)+$ Vermicompost $\left(1.5 \mathrm{t} \mathrm{ha}^{-1}\right)+$ Poultry manure $\left(2 \mathrm{t} \mathrm{ha}^{-1}\right)$ which was significantly superior over $\mathrm{T}_{2}\left(50 \% \mathrm{RDF}+\mathrm{FYM}\left(20 \mathrm{t} \mathrm{ha}^{-1}\right), \mathrm{T}_{3}\right.$ (50\% RDF + Vermicompost $\left(10 \mathrm{t} \mathrm{ha}^{-1}\right), \mathrm{T}_{4}(50 \% \mathrm{RDF}+$ Poultry manure $\left(4 \mathrm{t} \mathrm{ha}^{-1}\right), \mathrm{T}_{5}\left(50 \% \mathrm{RDF}+\mathrm{FYM}\left(7 \mathrm{tha}^{-1}\right)+\right.$ Vermicompost (3 $\left.\mathrm{t} \mathrm{ha}^{-1}\right)+$ Poultry manure $\left(1.5 \mathrm{t} \mathrm{ha}^{-1}\right), \mathrm{T}_{6}(50 \% \mathrm{RDF}+\mathrm{FYM}(10$ $\left.\mathrm{t} \mathrm{ha}^{-1}\right)+$ Vermicompost $\left(5 \mathrm{t} \mathrm{ha}^{-1}\right)$ and $\mathrm{T}_{10}$ Control, rest of the treatment ware at par. The minimum length of the spike $(60.70 \mathrm{~cm})$ was obtained in treatment $\mathrm{T}_{10}$ Control.

The effect of organic manures, inorganic fertilizers for Spike length, number of florets, were significantly influenced by the application of RDF $50 \%$ in combination with poultry manure $50 \%$ followed by RDF $50 \%$ in combination with poultry manure $25 \%$ and neem cake $25 \%$. This might be attributed to slow and sustained release of nutrients from poultry manure and neem cake. Ranjan, et al. (2014) ${ }^{[15]}$. Similar results have also been reported by Kumar and Singh (1998) ${ }^{[10]}$, Sharma et al. (2008) ${ }^{[18]}$, Tripathi et al. (2012) ${ }^{[22]}$ and Devi and Singh (2010) ${ }^{[7]}$ in tuberose. Spike length, rachis length and number of florets per spike are also positively influenced by the increasing doses of nitrogen, phosphorus and their interactions.

It is revealed from the data that average length of rachis was significantly influenced by various treatments under investigation. The maximum length of rachis $(30.89 \mathrm{~cm})$ was observed in treatment $\mathrm{T}_{9}\left(75 \% \mathrm{RDF}+\mathrm{FYM}\left(3.5 \mathrm{t} \mathrm{ha}^{-1}\right)+\right.$ Vermicompost $\left(1.5 \mathrm{t} \mathrm{ha}^{-1}\right)+$ Poultry manure $\left(2 \mathrm{t} \mathrm{ha}^{-1}\right)$ which was significantly superior over treatments $T_{2}, T_{3}, T_{4}, T_{5}, T_{6}$ and $\mathrm{T}_{10}$. However, it was statically at par with $\mathrm{T}_{1}, \mathrm{~T}_{7}$ and $\mathrm{T}_{8}$ treatments. The minimum length of rachis $(20.12 \mathrm{~cm})$ was observed with treatment $\mathrm{T}_{10}$ (Control). Chopde et al. (2007) ${ }^{[5]}$ and Yadav et al. (2005) ${ }^{[24]}$ also found highest length of rachis in tuberose with application of vermicompost. This might be due to integration of inorganic fertilizer like vermicompost which enhanced the plant growth and resulted in maximum length of spike, diameter of spike and length of rachis.

The finding revealed that the maximum number of florets spike $^{-1}$ (42.67) was counted in the treatment $\mathrm{T}_{9}(75 \% \mathrm{RDF}+$ FYM $\left(3.5 \mathrm{t} \mathrm{ha}^{-1}\right)+$ Vermicompost $\left(1.5 \mathrm{t} \mathrm{ha}^{-1}\right)+$ Poultry manure $\left(2 \mathrm{t} \mathrm{ha}^{-1}\right)$ and it was significantly superior except $\mathrm{T}_{1}$ $\left(100 \% \mathrm{RDF}, \mathrm{T}_{3}-50 \% \mathrm{RDF}+\right.$ Vermicompost $\left(10 \mathrm{t} \mathrm{ha}^{-1}\right)$, $\mathrm{T}_{7}\left(50 \% \mathrm{RDF}+\mathrm{FYM}\left(10 \mathrm{t} \mathrm{ha}^{-1}\right)+\right.$ Poultry manure $\left(2 \mathrm{t} \mathrm{ha}^{-1}\right)$ and $\mathrm{T}_{8}\left(50 \% \mathrm{RDF}+\right.$ Vermicompost $\left(5 \mathrm{tha}^{-1}\right)+$ Poultry manure $\left(2 \mathrm{t} \mathrm{ha}^{-1}\right)$ treatments. The minimum number of florets spike ${ }^{-1}$
(32.13) was observed in the treatment $\mathrm{T}_{10}$.

The beneficial effect of combined application of FYM, Vermicompost, Poultry manure was possible due to availability of essential macro and micro nutrients to the plants. Organic nutrients also protects plant from different insect, pest and disease, similar result were also found by (Purohit and Dushyant, 2006) ${ }^{[14]}$. With combined application of neem cake and inorganic fertilizers in tuberose and found maximum number of florets spike ${ }^{-1}$, and number of spikes per plant in tuberose.

Diameter of florets $(\mathrm{cm})$ the treatment effects were found to vary significantly for flower diameter as presented. The perusal of data clearly indicated that the maximum diameter of floret $(4.61 \mathrm{~cm})$ was recorded in treatment $\mathrm{T}_{7}(50 \% \mathrm{RDF}+$ FYM $\left(10 \mathrm{t} \mathrm{ha}^{-1}\right)+$ Poultry manure $\left(2 \mathrm{t} \mathrm{ha}^{-1}\right)$ which was significantly superior over treatments $T_{2}, T_{4}, T_{5}, T_{6}$, and $T_{10}$. However it was statistically at par with $\mathrm{T}_{1}, \mathrm{~T}_{3}, \mathrm{~T}_{7}, \mathrm{~T}_{8}$, and $\mathrm{T}_{9}$. The minimum diameter of floret $(1.47 \mathrm{~cm})$ was recorded in treatment $\mathrm{T}_{10}$ (Control). The results shows FYM and Poultry manure have significant effect on flower diameter of tuberose, where results were confirmity with the result of (Shubha 2006) ${ }^{[19]}$ who found maximum flower duration and diameter of flower with the treatment of Poultry manure $(12.5 \%)$.

The data regarding weight of 100 florets $(\mathrm{g})$ under different Treatments is presented. The different treatments of nutrient management had non significant influence on weight of 100 florets. However, the maximum weight of 100 florets was recorded in treatment $\mathrm{T}_{8}\left(50 \% \mathrm{RDF}+\right.$ Vermicompost $\left(5 \mathrm{t} \mathrm{ha}^{-1}\right)$ + Poultry manure $\left(2 \mathrm{t} \mathrm{ha}^{-1}\right)$ and minimum was noted in treatment $\mathrm{T}_{10}$ Control. The recommended dose application by combination of chemical similar trends were noted by Sharma et al. (2008) ${ }^{[18]}$, Singh et al. (1976) ${ }^{[20]}$, Yadav et al. (1985) ${ }^{[23]}$ and Chaudhary et al. (2007) ${ }^{[4]}$ in tuberose and organic sources have positive influence on fresh weight of 100 florets specially with application of $50 \%$ RDF + Vermicompost and Poultry manure combination.

It is evident from the table that maximum flower yield (1.50 $\left.\mathrm{kg} \mathrm{ha}^{-1}\right)$ was counted in the treatment $\mathrm{T}_{9}(75 \% \mathrm{RDF}+\mathrm{FYM}$ $\left(3.5 \mathrm{tha}^{-1}\right)+$ Vermicompost $\left(1.5 \mathrm{t} \mathrm{ha}^{-1}\right)+$ Poultry manure $(2 \mathrm{t}$ $\mathrm{ha}^{-1}$ ) which was significantly superior over treatments $\mathrm{T}_{2}, \mathrm{~T}_{3}$, $\mathrm{T}_{4}, \mathrm{~T}_{5}$ and $\mathrm{T}_{10}$. However it was statistically at par with $\mathrm{T}_{1}, \mathrm{~T}_{6}$, $\mathrm{T}_{8}$, and $\mathrm{T}_{9}$. The minimum flower yield $\left(0.50 \mathrm{~kg} \mathrm{ha}^{-1}\right)$ was observed in the treatment $\mathrm{T}_{10}$ (Control).Similar results were also reported by Singh, et al. $2006^{[2]}$. Who reported that poultry litter performed the best in respect of flower characters and flower yield followed by cow dung and vermicompost in tuberose. Similar result were also found by Padaganur, et al. $2005^{\text {[12] }}$. Who reported that poultry litter performed better report to flower yield than cow dung in tuberose. 
Table 3: Effect of nutrient management on length of spike, length of rachis, number of florets spike ${ }^{-1}$, diameter of florets, weight of 100 florets and flowers yield $\left(\mathrm{kg} \mathrm{m}^{-2}\right)$ in tuberose

\begin{tabular}{|c|c|c|c|c|c|c|}
\hline Treatments & $\begin{array}{l}\text { Length of } \\
\text { spike }(\mathrm{cm})\end{array}$ & $\begin{array}{l}\text { Length of } \\
\text { rachis }(\mathrm{cm})\end{array}$ & \begin{tabular}{|c|} 
Number of \\
florets spike $^{-1}$
\end{tabular} & $\begin{array}{l}\text { Diameter of } \\
\text { florets }(\mathbf{c m})\end{array}$ & $\begin{array}{c}\text { Weight of } \\
100 \text { florets }(g)\end{array}$ & \begin{tabular}{|c|}
$\begin{array}{c}\text { Flowers yield } \\
\left(\mathrm{kg} \mathrm{m}^{-2}\right)\end{array}$ \\
\end{tabular} \\
\hline $\mathrm{T}_{1}: 100 \%$ RDF (180:60:40) NPK & 70.10 & 28.66 & 39.43 & 4.27 & 124.67 & 1.35 \\
\hline $\mathrm{T}_{2}: 50 \% \mathrm{RDF}+\mathrm{FYM}\left(20 \mathrm{t} \mathrm{ha}^{-1}\right)$ & 68.29 & 26.30 & 35.87 & 3.00 & 124.63 & 0.85 \\
\hline $\mathrm{T}_{3}: 50 \%$ RDF + Vermicompost $\left(10 \mathrm{t} \mathrm{ha}^{-1}\right)$ & 66.27 & 25.77 & 39.61 & 4.24 & 124.33 & 0.95 \\
\hline $\mathrm{T}_{4}: 50 \% \mathrm{RDF}+$ Poultry manure $\left(4 \mathrm{t} \mathrm{ha}^{-1}\right)$ & 65.83 & 24.36 & 35.20 & 3.32 & 125.67 & 0.90 \\
\hline $\begin{array}{c}\mathrm{T}_{5}: 50 \% \text { RDF }+ \text { FYM }\left(7 \mathrm{t} \mathrm{ha}^{-1}\right)+\text { Vermicompost }\left(3 \mathrm{tha}^{-1}\right)+ \\
\text { Poultry manure }\left(1.5 \mathrm{tha}^{-1}\right)\end{array}$ & 66.29 & 26.00 & 35.76 & 3.99 & 125.03 & 1.00 \\
\hline $\mathrm{T}_{6}: 50 \%$ RDF + FYM $\left(10 \mathrm{t} \mathrm{ha}^{-1}\right)+$ Vermicompost $\left(5 \mathrm{t} \mathrm{ha}^{-1}\right)$ & 65.27 & 25.71 & 35.79 & 3.48 & 121.97 & 1.10 \\
\hline $\mathrm{T}_{7}: 50 \%$ RDF + FYM $\left(10 \mathrm{t} \mathrm{ha}^{-1}\right)+$ Poultry manure $\left(2 \mathrm{t} \mathrm{ha}^{-1}\right)$ & 69.55 & 27.76 & 39.97 & 4.61 & 124.67 & 1.30 \\
\hline $\begin{array}{c}\mathrm{T}_{8}: 50 \% \text { RDF + Vermicompost }\left(5 \mathrm{t} \mathrm{ha}^{-1}\right)+\text { Poultry manure }(2 \mathrm{t} \\
\left.\mathrm{ha}^{-1}\right)\end{array}$ & 70.30 & 27.95 & 39.66 & 4.41 & 127.33 & 1.25 \\
\hline $\begin{array}{c}\mathrm{T}_{9}: 75 \% \text { RDF + FYM }\left(3.5 \mathrm{tha}^{-1}\right)+\text { Vermicompost }\left(1.5 \mathrm{t} \mathrm{ha}^{-1}\right) \\
+ \text { Poultry manure }\left(2 \mathrm{t} \mathrm{ha}^{-1}\right)\end{array}$ & 72.33 & 30.89 & 42.67 & 4.17 & 124.00 & 1.50 \\
\hline $\mathrm{T}_{10}:$ Control & 60.70 & 20.12 & 32.13 & 1.47 & 118.68 & 0.50 \\
\hline S. Em \pm & 0.97 & 1.06 & 1.10 & 0.19 & 3.64 & 0.15 \\
\hline C.D at $5 \%$ & 2.91 & 3.17 & 3.27 & 0.43 & NS 10.81 & 0.48 \\
\hline
\end{tabular}

\section{Reference}

1. Alan O, Gunen Y, Ceylan S, Gunen E. Effect of nitrogen applicationson flower yield, some quality characteristics and leaf mineral content in tuberose (Polianthes tuberosa L.), Ege Tarimsal Arastirma Enstitusu Mudurlugu, Izmir, Turkey: Aegean Agriculture Research Ins. Direc. 2007; 17(1):43-57.

2. Amarjeet S, Godara NR, Ashok K, Singh A, Kumar A. Effect of NPK on flowering and flower quality of tuberose (Polianthes tuberosa L.) cv. single. Haryana Agriculture University Journal Research. 2000; 26(1):4349.

3. Chaoui I, Zibiliske M, Ohno T. Effect of earthworm easts and compost on soil microbial activity and plant nutrient availability, Soil Biol. Biochem. 2003; 35:295-302.

4. Chaudhary SS. Effect of nitrogen, phosphorus and biofertilizer application on plant growth and bulb production in tuberose. Haryana Journal of Horticultural Sciences. 2007; 36(1/2):82-85.

5. Chopde MP, Pillewan S, Bhongle SA. Integrated nutrient management in tuberose. Adv. Plant Sciences. 2007; 20 (2):443-444.

6. Dahiya SS, Mohansundram S, Singh S, Dahiya DS. Effect of nitrogen and phosphorus on growth and dry matter yield of tuberose (Polianthes tuberosa L.). Haryana Journal of Horticultural Sciences. 2001; 30(3/4):198-200.

7. Devi KL, Singh UC. Effect of nitrogen on growth, flowering and yield of tuberose (Polianthes tuberose L.) cv. Single. Journal of Ornamental Horticulture. 2010; 30(3):228-232.

8. Garg S, Bahla GS. Phosphorus availability to maize as influenced by organic manures, Biores. Technology. 2008; 99:773- 777.

9. Kabir AKMR, Iman MH, Mondal MMA, Chowdhury S. Response of Tuberose to Integrated Nutrient Management. Journal Environmental Sciences \& Natural Resources. 2011; 4(2):55-59.

10. Kumar S, Singh RP. Effect of nitrogen, bulb size and spacing on bulb and bulblet production of tuberose (Polianthes tuberosa L.). South Indian Horticulture. 1998; 46(3/6):294-298.

11. Padaganur VG, Mokashi AN, Patil VS. Flowering, flower quality and yield of tuberose as influenced by vermicompost and farmyard manure, Karnataka Journal of Agriculture Sciences. 2010; 18:729-734.
12. Padaganur VG, Mokashi AN, Patil VS. Flowering, Flower Quality and Yield of Tuberose (Polianthes tuberosa L.) as Influenced by Vermicompost, Farm yard Manure and Fertilizers. Karnataka Journal of Agriculture Sciences. 2005; 18(3):729-734.

13. Patil PR, Reddy BS, Patil SR, Kulkarni BS. Effect of community planting and fertilizer levels on growth and flower yield of tuberose (Polianthes tuberosa L.) cv. Double, South Indian Horticulture. 1999; 47(1/6):335338.

14. Purohit SS, Gehlot D. Trends in organic farming in India. Agrobios (India), 2006, 253-255.

15. Ranjan S, Preetham SP, Satish C. Effect of organic manures and biofertilizers on vegetative, floral and postharvest attributes in tuberose cv. Shringar. Asian Journal of biological and life sciences. 2014; 3(1):69.

16. Sadhu MK, Bose TK. Tuberose for most artistic garlands. Indian Hort.1973; 18(3):17-20.

17. Shankar L, Lakhawat SS, Choudhary MK. Effect of organic manures and biofertilizers on growth, flowering and bulb production in tuberose, Indian journal of Horticulture. 2010; 64:554-556.

18. Sharma JR, Panwar RD, Gupta RB, Singh S. Nutritional studies in tuberose (Polianthes tuberosa L.). Haryana Journal of Horticultural Sciences. 2008; 37(1/2):85-86.

19. Shubha BM. Integrated nutrient management for growth flowering and xanthophyll Yield of marigold (Tagetes erecta L.). M.Sc. (Ag.) Horticulture, thesis submitted to University of Agricultural sciences, Dharwad Karnataka, 2006.

20. Singh RS, Motial VS, Singh LB. Effect of nitrogen, phosphorous and potash fertilization on tuberose. Indian Journal of Horticulture. 1976; 33:289-294.

21. Singh SRP, Dhiraj K, Singh VK, Dwivedi R. Effect of NPK fertilizers on growth and flowering of tuberose cv. single. Journal of Horticulture Science. 2005; 34(1/2):84.

22. Tripathi SK, Malik S, Singh IP, Dhayani BP, Kumar V, Dhaka SS et al. Effect of integrated nutrient management on cut flower tuberose (Polianthes tuberosa L.) var. Suvasini. Annual of Horticulture. 2012; 5(1):108-115.

23. Yadav LP, Bose TK, Maity RG. Response of tuberose (Polianthes tuberosa L.) to nitrogen and phosphorus fertilization, Prog. Horticulture. 1985; 17(2):83-86.

24. Yadav LP, Bose TK, Naik RG. Response of tuberose to nitrogen and phosphorus fertilization. Prog. Horticulture. 2005; 17(2):83-86. 